\title{
Comparison of Heifer Weight Gains and Forage Quality for Continuous and Short- duration Grazing Systems
}

\author{
H.G. JUNG, R.W. RICE, AND L.J. KOONG
}

\begin{abstract}
A study of animal performance and forage quality under continuous and short-duration grazing (SDG) systems was conducted with post-weaning heifer calves on smooth bromegrass (Bromus inermis) pasture for 2 years. There were 8 paddocks for each SDG cell. The animals were on pasture from early May through the middle of August in both years. Heifers assigned to the SDG system were moved among the rotational paddocks approximately every 2.5 days. In 1982, the grazing treatments were stocked at equal levels ( 2.9 animals/ha). The stocking rate was increased to 3.8 animals/ha on the SDG treatment in 1983, while the continuous system remained at 2.9 animals/ha. Animals were weighed and forage samples were collected at the completion of each rotation cycle. Average daily gain (ADG) was similar (continuous $0.48 \mathrm{~kg} / \mathrm{d}$ vs. SDG $0.47 \mathrm{~kg} / \mathrm{d}, P>.05$ ) in 1982 when both systems were stocked equally. Available forage tended to be greater under the SDG system $(3,141 \mathrm{vs.} 3,786 \mathrm{~kg} / \mathrm{ha})$, but this difference was not significant. Forage quality did not differ $(P>.05)$ between the grazing systems but did decline significantly in both systems during the grazing season. Individual paddocks of the SDG system did not differ significantly in forage quality. In 1983, ADG was similar for both grazing systems $(0.56$ and $0.52 \mathrm{~kg} / \mathrm{d}, P>.05)$ and available forage also was similar $(2,551$ vs. $2,159 \mathrm{~kg} / \mathrm{ha})$. Crude protein content of the forage tended to be greater for the SDG system (7.9 vs. $8.5 \%, P<.05$ ) in 1983 . In vitro digestibility and crude protein content were lower, and cellulose and lignin concentrations were higher in forage from paddocks grazed later in the rotation sequence in 1983. The SDG system increased available forage when stocking rates were equal for the grazing systems, and this forage was effectively utilized at a higher stocking rate for the SDG system to produce more grain per ha (165.6 vs. $205.6 \mathrm{~kg} / \mathrm{ha})$ without sacrificing individual performance.
\end{abstract}

The use of short-duration grazing (SDG) systems to increase productivity of rangeland has received substantial interest recently (Heitschmidt and Walker 1983, Malechek and Dwyer 1983). This stems primarily from the claim of Savory and Parsons (1980) that a properly managed SDG system will generally result in a doubling of carrying capacity while maintaining equivalent levels of production per animal to those seen under more conventional systems. Experiments where stocking rates were equal for both continuous and SDG systems have resulted in equal animal gains (Sharrow and Krueger 1979). Accompanying this was an increase in available forage under the SDG system (Sharrow 1983). Rotational grazing increases plant growth rate (Chapman et al. 1983) and heavy grazing pressure results in more uniform use of pasture (Briske and Stuth 1982). These plant responses may account for the claims made for increased productivity under the SDG system.

The objective of this study was to compare forage responses to continuous and SDG systems. Available forage and quality mea-

Authors are research animal scientist, USDA, ARS, Roman L. Hruska US Meat Animal Research Center, Clay Center, Neb. 68933; professor, Department of Animal Science, University of Arizona, Tucson 85721; and research leader, Production Systems Unit, USDA, ARS, Roman L. Hruska US Meat Animal Research Center. L.J. Koong's present address is Associate Director, College of Agriculture, University of Nevada. Reno 89557.

Manuscript accepted June 7, 1984. surements were monitored throughout 2 grazing seasons. Effects of grazing sequence through the rotational paddocks on forage parameters was also studied. Performance of the cattle was monitored relative to the rotational cycles.

\section{Materials and Methods}

Replicated continuous and SDG systems were developed by dividing a 64.8-ha smooth bromegrass (Bromus inermis) pasture into 4 16.2-ha cells. Two of these cells were further subdivided into eight 2.0 -ha paddocks each with electric fencing. The SDG cells were arranged in a radial design with a central work and watering area. All cells were mowed in early spring, prior to initiation of active growth of the grass, and fertilized in April with $74 \mathrm{~kg} \mathrm{~N} /$ ha each year. Water and a mineral supplement were available to the cattle at all times. Angus, Hereford, Charolais, and Angus $X$ Hereford heifer calves born in September-October of the previous year were used. Breeds were allocated equally between grazing systems and cells, and mean weights were equalized among cells (222 kg in 1982, $231 \mathrm{~kg}$ in 1983).

In 1982, the continuous and SDG treatments were stocked with 2.9 animals/ha. Heifers assigned to the SDG system were rotated on a predetermined schedule averaging $2.5 \mathrm{~d}$ of grazing per rotational paddock (range 2-4 d). Rotation order through the paddocks remained constant, with $18.5 \mathrm{~d}$ of rest (range 17-19 d) after each grazing bout. In 1982, grazing was initiated on 12 May and terminated on 20 August after 5 complete cycles through the rotational paddocks. During the second year of the study, the continuously grazed cells were again stocked at 2.9 heifers/ha. However, the stocking rate of the rotational cells was increased to 3.8 animals/ha. Grazing was initiated 11 May 1983 and terminated 19 August 1983. The grazing interval per paddock and number of cycles was the same as the previous year. All cattle were weighed after completing each rotational cycle.

The available forage in each cell was sampled on the initiation date of the experiment each ycar and after completing each rotational cycle. Therefore, paddocks were sampled after varying lengths of rest from grazing $(0-18 d)$. Standing forage was clipped with hand shears from 42 quadrats $\left(0.09 \mathrm{~m}^{2}\right)$ in each continuously grazed cell and 6 quadrats were clipped in each paddock of the 2 rotationally grazed cells. Forage samples were dried in a forced-air oven at $70^{\circ} \mathrm{C}$ in 1982 and $45^{\circ} \mathrm{C}$ in 1983 . After grinding to pass a 1 $\mathrm{mm}$ screen, samples were analyzed for dry matter $\left(100^{\circ} \mathrm{C}\right)$, crude protein $(\mathrm{N} \times 6.25)$ and fiber components (Goering and Van Soest 1970). In vitro dry matter digestibility was determined according to Tilley and Terry (1963). All results are reported on a dry matter basis.

The data were analyzed as a split-plot design. Grazing systems were the whole plot and variation attributed to replicates within grazing systems served as whole plot error. Cycle or sampling date was the subplot main effect. The interaction of grazing treatment and cycle or sampling date was also tested in the subplot. Subplot error was the variation that remained after other effects in the model were accounted for. Data for 1982 and 1983 were analyzed separately. 


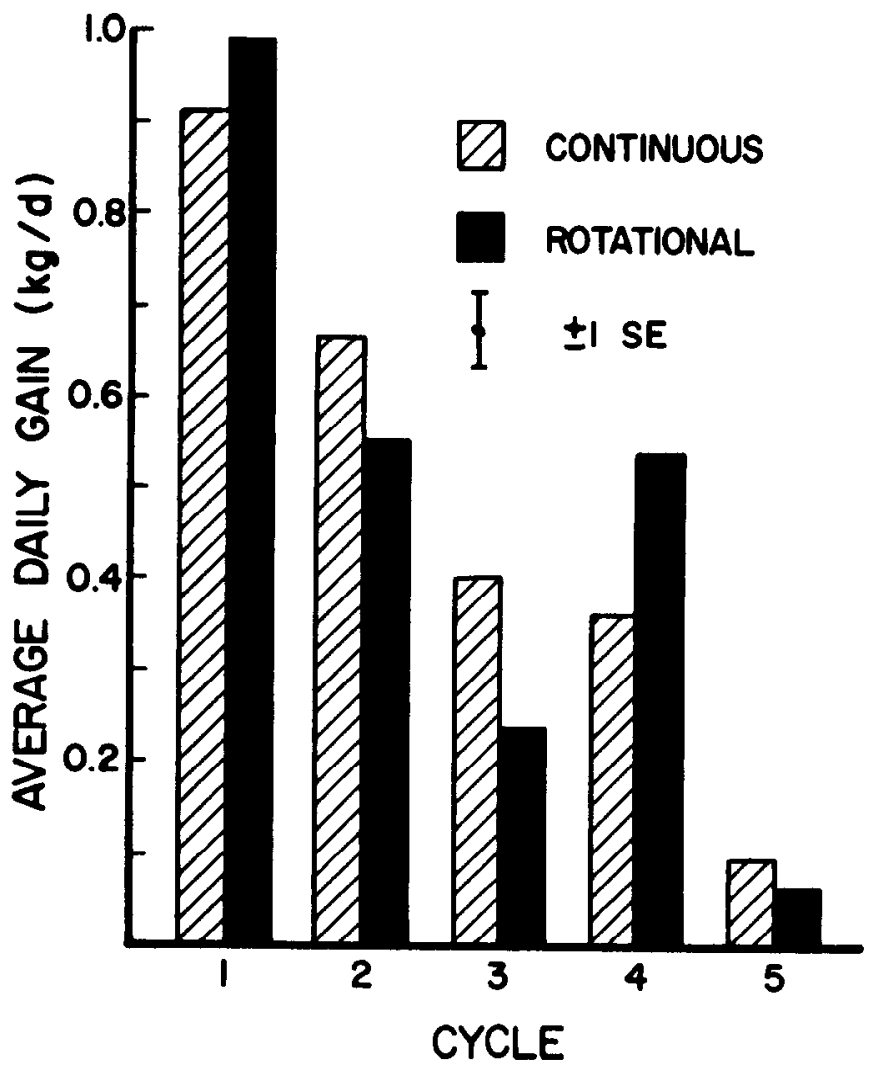

Fig. 1. Average daily gain of heifers on smooth bromegrass pasture for continuous and short-duration grazing systems through 5 rotational cycles in 1982. Grazing systems did not differ (P>.05) in gain.

\section{Results and Discussion}

\section{Animal Response}

Average daily gain (ADG) of heifers in 1982 is shown in Figure 1. Cattle grazing the continuous and SDG systems did not differ significantly in season-long ADG, but there was a decline $(P<.05)$ in $A D G$ as the grazing season progressed. There was no interaction of grazing system and progressive cycles. Gains averaged 0.48 and $0.47 \mathrm{~kg} / \mathrm{d}( \pm .07)$ across the entire grazing season for continuous and SDG systems, respectively. Numerous experiments have shown this result previously: equivalent gains per animal when both continuous and rotational grazing systems are stocked at the same level (Blazer et al. 1973). When the SDG system was stocked more heavily in 1983 (131\% of the continuous system), results (Fig. 2) were similar to those of the previous year. Grazing systems did not differ $(P>.05)$ in ADG nor was there an interaction of system with progressive cycles. However, there was a significant decline in ADG with progressive grazing cycles through the summer. Animal gain averaged 0.56 and $0.52 \mathrm{~kg} / \mathrm{d}$ (土.05) over the entire grazing season for the continuous and SDG systems respectively. While productivity remained the same per animal between grazing systems, total productivity per hectare increased $24.2 \%$ between the continuous and SDG systems (165.6 vs $205.7 \mathrm{~kg}$ of gain/ha, $P=$ $.05)$ due to the increased stocking rate. This pattern of equal gain per animal and increased gain/ ha has been reported previously for SDG systems (Heitschmidt et al. 1982a) and supports the claim of Savory and Parsons (1980).

\section{Forage Availability}

In 1982, available forage did not differ significantly between grazing systems, although there appeared to be $36 \%$ morc foragc present under the SDG system on 21 June 1982 and available forage remained greater throughout the remainder of the summer

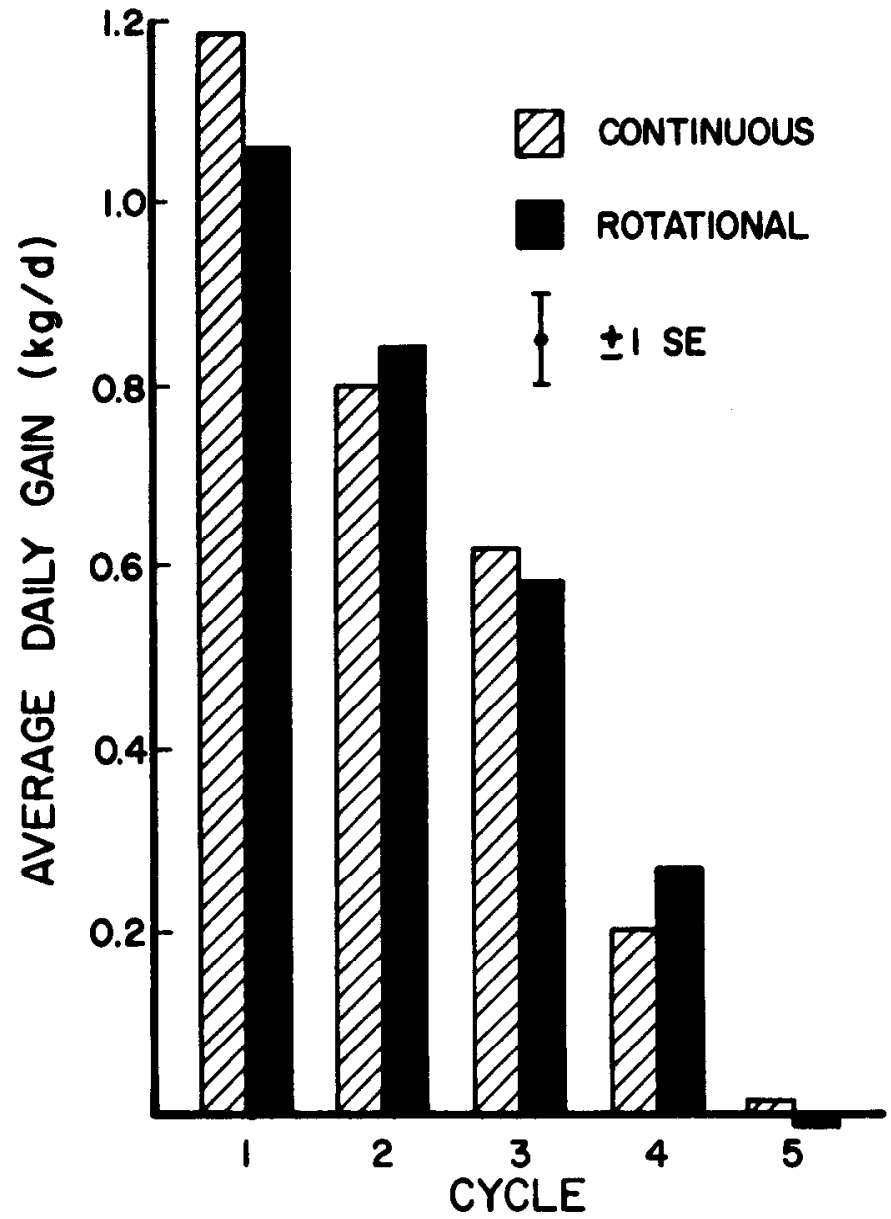

Fig. 2. Average daily gain of heifers on smooth bromegrass pasture for continuous and short-duration grazing systems through 5 rotational cycles in 1983. Grazing systems did not differ $(\mathbf{P}>0.5)$ in gain.

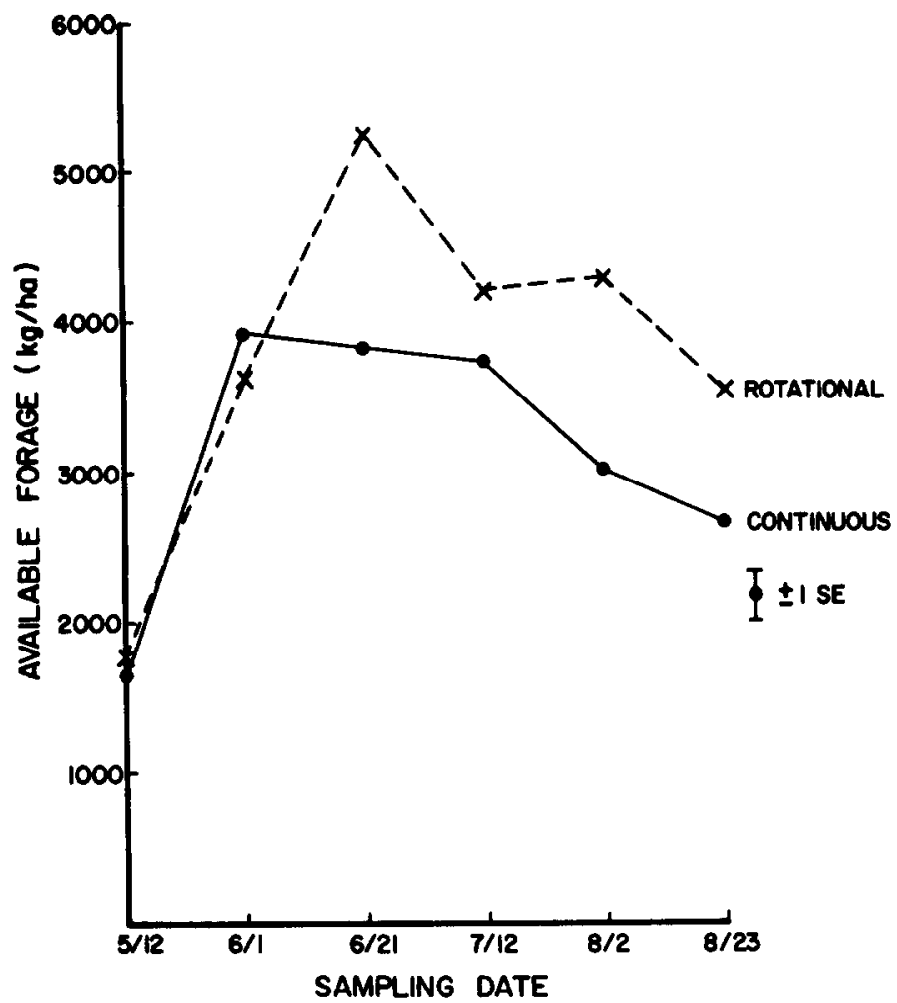

Fig. 3. Available standing forage in the continuously and short-duration grazing system during 1982. Grazing systems did not differ $(\mathrm{P}>.05)$ in available forage. 
(Fig. 3). Available forage was different $(P<.05)$ among sampling dates, but there was no interaction of grazing system and sampling date for available forage. There was also no overall grazing system effect on available forage in 1983 (Fig. 4). Again available forage was different $(P<.05)$ with sampling date and the effect of sampling date and its interaction with grazing system was significant. Available forage was greater $(P<.05)$ under the continuous grazing system on 1 August 1983 (2,730 vs. $1,381 \mathrm{~kg} / \mathrm{ha})$.

Sharrow (1983) has previously reported an increase in available forage on annual grass-subclover (Trifolium subterraneum) pastures when grazed by ewes and lambs rotationally as opposed to a continuous system. The stocking rate of the SDG system was increased in 1983 in an attempt to utilize the increased available forage of this system. The similarity of available forage between the grazing systems in 1983 indicates that the forage was more effectively utilized under the SDG system at the higher stocking rate. It has been shown that grasses which are rotationally grazed have greater growth rates (Chapman et al. 1983). This altered growth rate may explain the greater available forage levels of the SDG cells in 1982 and equivalent levels in 1983, under an elevated grazing intensity, relative to the continuous system. The doubling of available forage in 1982 and 1983 for both grazing systems during the first 2 grazing cycles suggests that both systems were understocked during the rapid growth phase of the smooth bromegrass. However, more complete utilization of the forage early in the season would probably necessitate use of other pastures during the summer when smooth bromegrass is dormant.

\section{Forage Quality}

Chemical composition of the forage did not differ $(P>.05)$ between grazing systems in 1982, but was significantly different among sampling dates. Mean forage quality values, pooled across systems, for sampling dates are given in Table 1. Crude protein concentration declined; whereas cell wall, cellulose and lignin concentrations increased during the summer. Hemicellulose content of

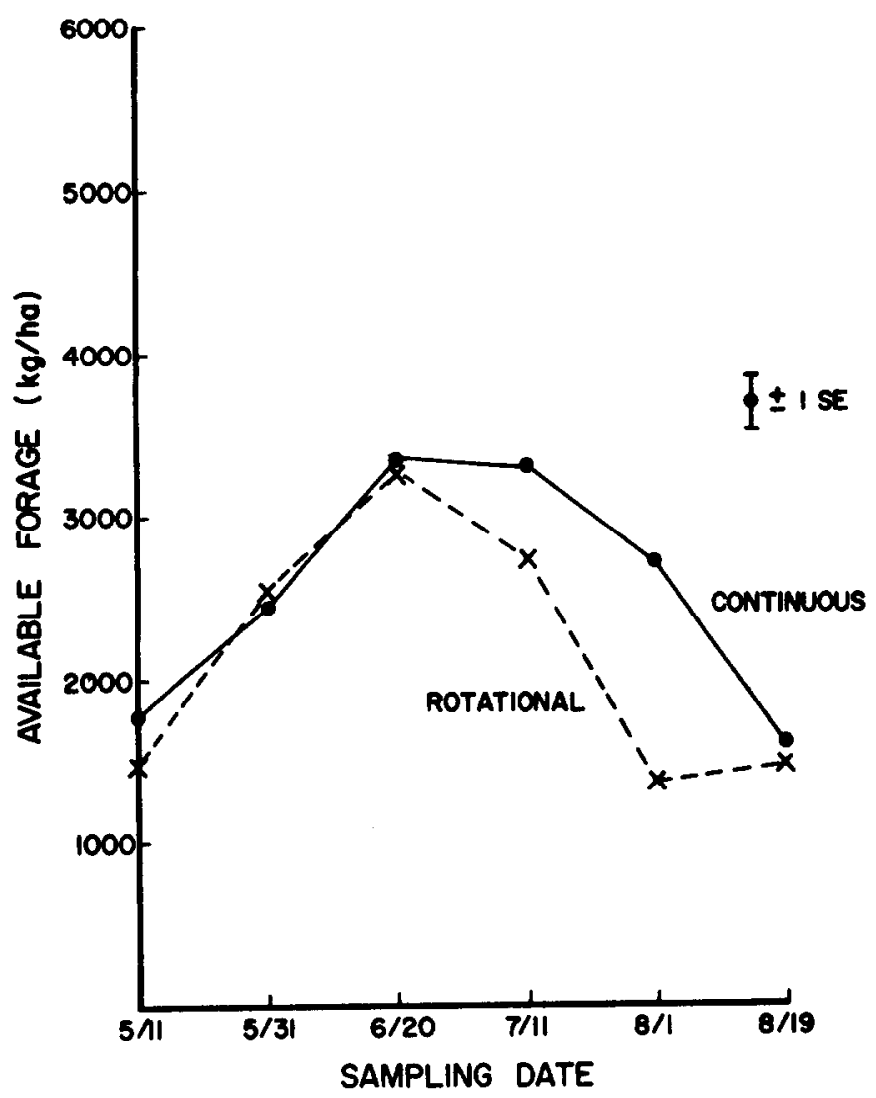

Fig. 4. Available standing forage in the continuously and short-duration grazing systems during 1983. Grazing systems were different $(\mathrm{P}>.05)$ in available forage on 1 August.

Table 1. Mean in vitro dry matter digestibility (IVDMD) and chemical composition of smooth bromegrass forage, averaged across grazing systems, collected during 1982 from both continuous and short-duration grazing systems.

\begin{tabular}{|c|c|c|c|c|c|c|}
\hline \multirow[b]{2}{*}{ Sampling date } & \multirow[b]{2}{*}{ IVDMD $(\%)$} & \multicolumn{5}{|c|}{ Chemical composition $(\%)^{!}$} \\
\hline & & $\mathrm{CP}$ & $\mathrm{CW}$ & CEL & $\mathrm{HC}$ & L \\
\hline 12 May & $65.6^{\mathrm{a}}$ & $21.2^{\mathrm{a}}$ & $61.2^{\mathrm{a}}$ & $28.0^{\mathrm{a}}$ & $30.0^{\mathrm{a}}$ & $3.2^{\mathrm{a}}$ \\
\hline I June & $66.2^{\mathrm{a}}$ & $13.1^{\mathrm{b}}$ & $63.6^{\mathrm{b}}$ & $28.9^{b}$ & $31.4^{\mathrm{b}}$ & $3.2^{\mathrm{a}}$ \\
\hline 21 June & $57.7^{b}$ & $8.8^{c}$ & $63.6^{b}$ & $30.2^{\mathrm{c}}$ & $29.7^{\mathrm{ac}}$ & $3.7^{\mathrm{b}}$ \\
\hline 12 July & $50.9^{\mathrm{c}}$ & $7.4^{\mathrm{d}}$ & $62.7^{\mathrm{ab}}$ & $30.4^{\mathrm{c}}$ & $28.1^{\mathrm{d}}$ & $4.1^{\mathrm{c}}$ \\
\hline 2 August & $44.7^{d}$ & $6.5^{\mathrm{e}}$ & $65.9^{\circ}$ & $32.5^{\mathrm{d}}$ & $28.8^{\mathrm{ed}}$ & $4.7^{\mathrm{d}}$ \\
\hline 22 August & $34.9^{e}$ & $5.5^{\mathrm{f}}$ & $72.4^{\mathrm{d}}$ & $35.9^{\mathrm{e}}$ & $30.9^{\mathrm{b}}$ & $5.7^{e}$ \\
\hline $\mathrm{SE}^{2}$ & .8 & 3 & .6 & .3 & .3 & .1 \\
\hline
\end{tabular}

ICP (crude protein); CW (cell wall); CEL (cellulose); HC (hemicellulose); L (lignin).

${ }^{2} \mathrm{SE}$ (standard error of the mean).

aboder Means in the same column not sharing a common superscript differ $(P<.05)$.

Table 2. Mean in vitro dry matter digestibility (IVDMD) and chemical composition of smooth bromegrass forage, averaged across grazing systems, collected during 1983 from both continuous and short-duration grazing systems.

\begin{tabular}{|c|c|c|c|c|c|c|}
\hline \multirow[b]{2}{*}{ Sampling date } & \multirow[b]{2}{*}{ IVDMD(\%) } & \multicolumn{5}{|c|}{ Chemical composition $(\%)^{\prime}$} \\
\hline & & $\mathrm{CP}$ & $\mathrm{CW}$ & CEL & $\mathrm{HC}$ & $\mathbf{L}$ \\
\hline $\begin{array}{l}11 \text { May } \\
31 \text { May } \\
20 \text { June } \\
11 \text { July } \\
1 \text { August } \\
19 \text { August } \\
\text { SE}^{2}\end{array}$ & $\begin{array}{c}73.6^{\mathrm{a}} \\
77.9^{\mathrm{b}} \\
66.4^{\mathrm{c}} \\
58.7^{\mathrm{d}} \\
53.8^{\mathrm{e}} \\
48.9^{\mathrm{f}} \\
.8\end{array}$ & $\begin{array}{c}17.1^{\mathrm{a}} \\
11.1^{\mathrm{b}} \\
7.1^{\mathrm{c}} \\
6.2^{\mathrm{d}} \\
4.0^{\mathrm{e}} \\
3.6^{\mathrm{e}} \\
.1\end{array}$ & $\begin{array}{c}55.0^{\mathrm{a}} \\
60.4^{\mathrm{b}} \\
67.3^{\mathrm{c}} \\
66.7^{\mathrm{c}} \\
69.7^{\mathrm{d}} \\
74.4^{\mathrm{e}} \\
.6\end{array}$ & $\begin{array}{c}25.7^{\mathrm{a}} \\
26.8^{\mathrm{a}} \\
31.3^{\mathrm{b}} \\
31.5^{\mathrm{b}} \\
34.6^{\mathrm{c}} \\
37.6^{\mathrm{d}} \\
.4\end{array}$ & $\begin{array}{c}26.1^{\mathrm{a}} \\
31.0^{\mathrm{b}} \\
31.9^{\mathrm{c}} \\
30.7^{\mathrm{bd}} \\
30.3^{\mathrm{d}} \\
31.4^{\mathrm{bc}} \\
.2\end{array}$ & $\begin{array}{l}3.2^{\mathrm{a}} \\
2.5^{\mathrm{b}} \\
4.0^{\mathrm{c}} \\
4.4^{\mathrm{d}} \\
4.8^{\mathrm{e}} \\
5.4^{\mathrm{f}} \\
.1\end{array}$ \\
\hline
\end{tabular}

ICP (crude protein); CW (cell wall); CEL (cellulose); HC (hemicellulose); L (lignin). 2SE (standard error of the mean).

abder Means in the same column not sharing a common superscript differ $(P<.05)$. 
the forage declined through July, but showed an increase toward the end of the summer. Crude protein concentration exhibited an interaction between grazing system and sampling date. Only the initial (12 May 1982) crude protein content of the forages was different $(P<05)$, with the continuous grazing system being greater (22.2 vs. $20.2 \%)$ than SDG. This difference may reflect sampling error. In vitro dry matter disappearance (IVDMD) declined $(P<.05)$ during the summer and the forage from the continuous grazing system had a higher $(P<.05)$ IVDMD than the SDG (55.3 vs. $51.3 \%$ ). However, the interaction of the grazing system and sampling date was also significant, with only 12 May and 2 August 1982 being higher in IVDMD for the continuous grazing system. Again this sporadic difference may be due to sampling. In 1983 no differences existed for any of the forage characteristics between the 2 grazing systems, therefore, chemical composition and IVDMD of the forage are given in Table 2 averaged across both grazing systems. All the forage characteristics were different $(P<.05)$ with regard to sampling date. Crude protein concentration and IVDMD declined, whereas cell wall, cellulose, and lignin concentrations increased with progressive sampling date. Hemiccllulose content of the forage changed with sampling date, but not in a consistent manner. Crude protein and hemicellulose concentrations exhibited an interaction between grazing system and sampling date. Forage crude protein concentration was lower $(P<.05)$ for the continuous system versus SDG on 31 May 1983 (10.5 vs. 11.7\%), 11 July 1983 (5.6 vs. 6.9\%), and 1 August 1983 (3.7 vs. 4.3\%). HemicelJulose content was lower $(P<.05)$ for forage from the continuous grazing system ( 24.2 vs. $28.1 \%)$ on the initiation date of grazing only, again suggesting a sampling error.

Since grazing intensity was high in each paddock of the SDG system during the time they were actually grazed, it would be expected that forage quality would be higher in the SDG cells than for the continuous system because a larger percentage of the plants should have been grazed and, therefore, retarded in maturity. Heavy grazing pressure has been used to delay maturation of grasses (Norton et al. 1982). In fact, there were no differences in quality, based on chemical composition, between grazing systems. The IVDMD of the forage in the continuously grazed cells in 1982 even tended to be higher than that of the SDG treatment. This suggests that either both grazing systems were understocked, allowing the forage to reach physiological maturity, or the growth rate of the forage was sufficiently rapid for the grass to become mature during regrowth of the rotational paddocks during their rest periods. The lack of differences in forage quality in 1983 between the grazing systems suggests that the elevated stocking rate for the SDG system was still too low to delay forage maturation, although crude protein content did tend toward higher concentrations under the rotational system. Savory (1983) emphasizes the importance of timing of grazing with forage growth rate. Too long rest periods in the early portion of the grazing season may have allowed the forage to become mature in this study.

Grazing of a pasture sward has been found to result in a decrease in the quality of the remaining available forage (Heitschmidt et al. 1982b). This is undoubtably due to selectivity of grazing ruminants such that the highest quality forage is removed, leaving the lower quality material. Therefore, while overall quality of forage in a rotationally grazed system may not differ from a continuously grazed pasture, paddocks within the SDG should differ in forage quality if sampled on the same date because of different lengths of regrowth. Forage characteristics of the individual paddocks in 1982 within the rotational system are presented in Table 3. Available forage and cellulose concentration were the only measurements

Table 3. Available forage, in vitro dry matter digestibility (IVDMD) and chemical composition of forage from rotationally grazed paddocks in 1982. Values are means across sampling dates.

\begin{tabular}{|c|c|c|c|c|c|c|c|}
\hline \multirow{2}{*}{$\begin{array}{r}\text { Rotational } \\
\text { Paddock }\end{array}$} & \multirow{2}{*}{$\begin{array}{c}\text { Available } \\
\text { forage }(\mathrm{kg} / \mathrm{ha})\end{array}$} & \multirow[b]{2}{*}{ IVDMD (\%) } & \multicolumn{5}{|c|}{ Chemical composition (\%) ${ }^{1}$} \\
\hline & & & $\mathrm{CP}$ & $\mathrm{CW}$ & CEL & $\mathrm{HC}$ & $\bar{L}$ \\
\hline 1 & $4009^{\mathrm{ac}}$ & 50.2 & 10.3 & 65.8 & $31.4^{\text {acd }}$ & 30.1 & 4.3 \\
\hline 2 & $3167^{b}$ & 53.8 & 10.9 & 64.1 & $30.0^{b}$ & 30.1 & 4.0 \\
\hline 3 & $4204^{\mathrm{ac}}$ & 51.4 & 10.6 & 66.2 & $31.5^{\text {acd }}$ & 30.4 & 4.4 \\
\hline 4 & $3966^{\mathrm{ac}}$ & 51.9 & 10.3 & 65.0 & $30.8^{\mathrm{ab}}$ & 30.1 & 4.2 \\
\hline 5 & $3730^{a}$ & 50.0 & 10.2 & 64.9 & $31.1^{\mathrm{ac}}$ & 29.8 & $\begin{array}{l}4.2 \\
4.0\end{array}$ \\
\hline 6 & $4129^{\mathrm{ac}}$ & 50.1 & 9.9 & 65.6 & $31.9^{\text {ed }}$ & 29.4 & 4.3 \\
\hline 7 & $4338^{c}$ & 52.7 & 9.9 & 64.8 & $31.3^{\mathrm{ac}}$ & 29.4 & 4.2 \\
\hline 8 & $2749^{b}$ & 50.4 & 10.0 & 66.6 & $32.2^{\mathrm{d}}$ & 29.9 & 4.5 \\
\hline $\mathrm{SE}^{2}$ & 193 & 1.1 & .3 & .4 & .3 & .2 & .1 \\
\hline
\end{tabular}

CP (crude protein); CW (cell wall); CEL (cellulose); HC (hemicellulose); L. (lignin).

${ }^{2} \mathrm{~S} E$ (standard crror of the mean).

Means in the same column not sharing common superscripts differ $(R<.05)$

Table 4. Available forage, in vitro dry matter digestibility (IVDMD) and chemical composition of forage from rotationally grazed paddocks in 1983. Values are means across sampling dates.

\begin{tabular}{|c|c|c|c|c|c|c|c|}
\hline \multirow{2}{*}{$\begin{array}{r}\text { Rotational } \\
\text { Paddock } \\
\end{array}$} & \multirow{2}{*}{$\begin{array}{c}\text { Available } \\
\text { forage }(\mathrm{kg} / \mathrm{ha})\end{array}$} & \multirow[b]{2}{*}{ IVDMD $(\%)$} & \multicolumn{5}{|c|}{ Chemical composition $(\%)^{1}$} \\
\hline & & & $\mathrm{CP}$ & $\mathrm{CW}$ & CEL & $\mathrm{HC}$ & $\mathbf{L}$ \\
\hline 1 & 2582 & $64.2^{\mathrm{ac}}$ & $8.6^{\mathrm{ac}}$ & 65.4 & $31.0^{\mathrm{ab}}$ & 30.2 & $4.1^{\mathrm{ac}}$ \\
\hline 2 & 2074 & $64.6^{\mathrm{ac}}$ & $9.0^{\text {abc }}$ & 65.8 & $30.6^{\mathrm{bc}}$ & 31.2 & $3.9^{\mathrm{b}}$ \\
\hline 3 & 2209 & $62.7^{\mathrm{b}}$ & $8.6^{\mathrm{ac}}$ & 65.7 & $31.3^{\mathrm{abd}}$ & 30.1 & $4.2^{\mathrm{a}}$ \\
\hline 4 & 1808 & $65.5^{\mathrm{c}}$ & $9.0^{\mathrm{ab}}$ & 64.9 & $30.2^{\mathrm{c}}$ & 30.7 & $3.9^{\mathrm{bc}}$ \\
\hline 5 & 1799 & $64.1^{\mathrm{ab}}$ & $9.4^{\mathrm{b}}$ & 66.4 & $30.6^{b c}$ & 31.5 & $4.1^{\mathrm{mc}}$ \\
\hline 6 & 2389 & $61.1^{\mathrm{d}}$ & $7.9^{\mathrm{d}}$ & 67.4 & $31.9^{d}$ & 31.1 & $4.3^{\mathrm{a}}$ \\
\hline 7 & 2450 & $62.7^{\mathrm{b}}$ & $8.2^{\mathrm{cd}}$ & 66.2 & $31.6^{\text {ad }}$ & 30.1 & $4.4^{n}$ \\
\hline 8 & 1959 & $63.1^{\mathrm{ab}}$ & $7.6^{\mathrm{d}}$ & 66.4 & $31.7^{\mathrm{ad}}$ & 30.5 & $4.2^{\mathrm{ac}}$ \\
\hline $\mathrm{SE}^{2}$ & 167 & .5 & .2 & .5 & .3 & .3 & .1 \\
\hline
\end{tabular}

'CP (crude protein); CW (cell wall); CEL (cellulose); HC (hemicellulose); L (lignin).

${ }_{\text {abcd }}^{2}$ (standard error of the mean).

Means in the same column not sharing a common superscript differ $(P<05)$. 
which were different $(P<.05)$ among the paddocks. There were, however, no discernible trends for available forage or cellulose concentration with grazing sequence through the paddocks. All the pasture measurements exhibited significant trends with sampling date which were the same as those seen in Table 1 and Figure 3. There were no interactions between paddocks and sampling date for forage characteristics. In 1983, several quality measurements were depressed, but only slightly, in the paddocks of the latter half of the grazing sequence. Forage characteristics from the paddocks within the SDG system in 1983 are presented in Table 4 . There were significant differences among paddocks for IVDMD, crude protein, cellulose, and lignin concentrations. The forage in the later grazed paddocks $(6,7$, and 8$)$ tended to be lower in quality measurements than the forage from paddocks grazed earlier. The significant sampling date effect on forage characteristics followed those seen in Table 2. However, the interaction of paddock and sampling date was significant for cellulose and lignin concentration, and IVDMD of the forage. Examination of the means of these measurements for individual paddocks and sampling dates revealed the same pattern as seen earlier for the paddocks averaged across sampling dates (Table 4). Forage from paddocks grazed later in the sequence $(6,7$, and 8$)$ was lower $(P<.05)$ in IVDMD and higher $(\mu<.05)$ in cellulose and lignin content than forage from the earlier paddocks, but this pattern did not appear until the later sampling dates (11 July, 1 and 19 August 1983). The tendency for forage quality to be lower in the later grazed paddocks was expected based on selective grazing (Heitschmidt et al. 1982b) and length of regrowth since the grazing interval. The fact that these forage quality differences with rotation sequence for paddocks did not develop till late in the season, and only in 1983, provides further evidence that the SDG cells were probably understocked in both years.

\section{Literature Cited}

Blaser, R.E., D.D. Wolfe, and H.T. Bryant. 1973. Systems of grazing management. p. 581-595. In: Forages: The science of grassland agriculture. M.E. Heath, D.S. Metcalfe and R.F. Barnes (eds). Iowa State Univ. Press, Ames.

Briske, D.D., and J.W. Stuth. 1982. Tiller defoliation in a moderate and heavy grazing regime. J. Range Manage. 35:511-514.

Chapman, D.F., D.A. Clark, C.A. Land, and N. Dymock. 1983. Leaf and tiller growth of Lolium perenne and Agrostis spp. and leaf appearance rates of Trifolium repens in set-stocked and rotationally grazed hill pastures. N.Z.J. Agr. Res. 26:159-168.

Goering, H.K., and P.J. Van Soest. 1970. Forage fiber analysis (apparatus, reagents, procedures and some applications). USDA Agr. Handb. 379, Washington, D.C.

Heitschmidt, R.K., J.R. Frasure, D.L. Price, and L.R. Rittenhouse. 1982a. Short duration grazing at the Texas Experimental Ranch: Weight gains of growing heifers. J. Range Manage. 35:375-379.

Heitschmidt, R.K., R.A. Gordon, and J.S. Bluntzer. 1982b. Short duration grazing at the Texas Experimental Range: Effects on forage quality. J. Range Manage. 35:372-374.

Heitschmidt, R., and J. Walker. 1983. Short duration grazing and the Savory Grazing Method in perspective. Rangelands 5:147-150.

Malechek, J.C., and D.D. Dwyer. 1983. Short-duration grazing doubles your livestock? Utah Sci. 44:32-37.

Norton, B.E., P.S. Johnson, and M.K. Owens. 1982. Increasing grazing efficiency on crested wheatgrass. Utah Sci. 43:110-113.

Savory, A. 1983. The Savory Grazing Method or holistic resource management. Rangelands. 5:155-159.

Savory, A., and S.D. Parsons. 1980. The Savory Grazing Method. Rangelands. 2:234-237.

Sharrow, S.H. 1983. Forage standing crop and animal diets under rotational vs. continuous grazing. J. Range Manage. 36:447-450.

Sharrow, S.H., and W.C. Krueger. 1979. Performance of sheep under rotational and continuous grazing on hill pastures. J. Animal Sci. 49:893-899.

Tilley, J.M.A., and R.A. Terry. 1963. A two-stage technique for the in vitro digestion of forage crops. J. Brit. Grassland Soc. 18:104-111.

\title{
RANGELAND HYDROLOGY
}

\author{
by Farrel A. Branson, Gerald F. Gifford, Kenneth G. Renard, and \\ Richard F. Hadley
}

Unique in its emphasis on the hydrology of rangelands, primarily arid and semiarid lands, RANGELAND HYDROLOGY provides a text for one aspect of range management where none has existed before. This expanded Second Edition presents in-depth information for those who must manage rangeland or respond to questions about the impacts of land use practices on hydrology.

Included in the new Second Edition are a chapter on modeling with approaches to predicting the effects of land use, and a chapter on the rapidly developing field of snow pack management.

The 352-pages include 197 illustrations, providing rapid access to an assembly of data found nowhere else and useful in the preparation of environmental impact statements. Extensive bibliographic material with each chapter and a subject matter index add to the useableness of the book.

Range scientists and managers, soil conservationists, hydrologists, agricultural engineers, land reclamation specialists, wildlife managers, graduate and undergraduate students and their professors, as well as all interested in the hydrology of arid lands will find RANGELAND HYDROLOGY a valuable addition to their libraries. (352 pages paper laminated cover $\$ 15.00$ US) 